\title{
Islamic Critical Theory: A Tool for Emancipatory Education
}

\author{
FAWZIA GILANI-WILLIAMS ${ }^{1}$
}

\begin{abstract}
Essentially all theories used in the West are secular based. This is problematic for Western Muslim researchers who investigate the world through an Islamocentric lens. This paper was developed as part of an action research project that investigated Islamic literature-based character development with elementary school children. In developing a theoretical framework Critical Theory and critical pedagogy were initially researched, however, their Marxist origins conflicted with an Islamic worldview. As a result I researched Islamic Critical Theory and critical Islamic pedagogy. Whilst Islamic pedagogy is being used in the West in some circles, the concept of Islamic Critical Theory was mentioned by only three scholars: Kazmi, Sharify-Funk and Sadek. Seeking a theoretical framework that was aligned to the Islamic worldview led me to develop a version of Islamic Critical Theory based on Horkheimer's three criteria definition. I argue that this type of Islamic Critical Theory can critique every aspect of life and present a solution that is in harmony with the teachings of the Quran and Sunnah and can lead to emancipation, transformation and a better life. This paper essentially demonstrates how Islamic Critical Theory is an emancipatory theory. The paper begins with a discussion of Critical Theory and critical pedagogy to show how they inform Islamic Critical Theory. It then discusses how Kazmi, Sharify-Funk and Sadek use the term. It then enumerates on the characteristics of Islamic Critical Theory and ties these to give historic origins dating to the re-emergence of the Islamic message in the Arabian Peninsula.
\end{abstract}

Keywords: Critical Theory, emancipation, Islam, Islamic Critical Theory

Traditional theories are concerned with understanding and explaining what is happening so their agenda goes no further than discussion. Critical Theory, however, is different because it not only critiques but it seeks to make changes. It is political. Critical Theory seeks to emancipate and transform those who are oppressed and marginalized through functional steps:

\begin{abstract}
Critical theory is politically committed in the sense that it aims to achieve emancipation and transformation of individuals and society through human action. Theory and practice form a single process and philosophy is 'put to work' to provide analysis and critique of society and leading to social change (Jessop 2010: 3).
\end{abstract}

It was Horkheimer of the Frankfurt School who initially coined the term Critical Theory. The Frankfurt School which was also known as the Institute for Social Research, was originally located in Germany but then moved to New York when the Nazis forced its closure and exiled its Jewish members (McLaughlin 1999: 110). Key developers of Critical Theory include Horkheimer, Adorno, Marcuse and later Habermas who formed the second generation. Critical Theory emerged from a group of men who saw the atrocities inflicted by humans on humans.

\footnotetext{
${ }^{1}$ Fawzia Gilani-Williams, Ph.D. Student at the University of Worcester, WORCESTER WR2 6AJ, United Kingdom, email: fawziagilani@yahoo.com.
} 
The scholars from the Frankfurt School wanted to understand how people could act the way they did but also how such behaviour could be stopped. Although the scholars were Jewish, Kellner (n.d.) states:

The Frankfurt School had a highly ambivalent relation to Judais ... They were also, for the most part, secular Jews who did not support any organized religion, or practice religious or cultural Judaism. In this sense, they were in the tradition of Heine, Marx, and Freud for whom Judaism was neither a constitutive feature of their life or work, nor a significant aspect of their self-image and identity.

Despite the Frankfurt scholars being religiously detached, their focus in developing Critical Theory was 'nothing less than the discovery of why mankind, instead of entering a truly human condition, is sinking into a new kind of barbarism' (Adorno \& Horkheimer 1997: xi). The function of Critical Theory is empowerment, it seeks to encourage transformation for those 'whose voices are silenced or marginalised' (Bercaw \& Stooksberry 2004). After critiquing society and understanding 'what is', it then asks 'what should be' to create a 'better life' (How 2003: 9). Developers of Critical Theory saw how mass media or the culture industry 'played a highly manipulative role in modern society and served to control or subvert oppositional consciousness, thus removing any threat to the dominant capitalist class' (Strauss: 2012). The demonization of the Muslim masses is a good example of subverting 'oppositional consciousness'.

According to Habermas, 'critical knowledge was conceptualized as knowledge that enabled human beings to emancipate themselves from forms of domination through selfreflection and took psychoanalysis as the paradigm of critical knowledge' (Huttunen 2011). Habermas developed the theory of communicative action. This was a way that people could work together and produce positive social transformation. The theory of communicative action refers to interpersonal communication geared towards mutual understanding. Mutual understanding leads to mutual civility and this works to exclude barbarity. I will discuss the Islamic equivalent of this theoretical perspective later in my introduction to Islamic critical theory:

Actors do not primarily aim at their own success but want to harmonize their action plans with the other participants. Opposite to communicative action is the concept of strategic action, which means calculative exploitation, or manipulation, of others. An actor who acts strategically seeks primarily his or her own ends and manipulates other people either openly or tacitly (Habermas 1984: 285).

\section{Critical Pedagogy}

Critical pedagogy was initially based on Marxist theory (Lyles 2008: 38). 'Historically, critical pedagogy was perceived to be one realization of the critical theory of the Frankfurt School' (Breuing 2011: 4). However, critical pedagogy has now branched off into the various disciplines that use it. Similar to Critical Theory, critical pedagogy is not only a theory but also a practical educational philosophy. Paulo Freire was one of the first to create this radical educational and socially steering movement. Leading academics who embraced the philosophy include Kincheloe, McLaren, Giroux, Shor and Macedo (Duncan-Andrade \& Morrell 2008). Critical pedagogy is concerned with social justice. In his most influential work, Pedagogy of the Oppressed (1968), Freire understood schools to be 'impediments to the education of the poor, and thus sought to find strategies for students to intervene in what he considered to be a dehumanizing process' (Breuing 2011: 4). He called for the liberation of the oppressed through learning. The focus of critical pedagogy is therefore to empower students with a critical lens. 
Freire although born to a middle class family was exposed to hunger and poverty during the depression in Brazil. This initiated a life-long concern to help the poor; he did this in a number of ways, one of which was to bring literacy to the underprivileged. Through his own experience of hunger, Freire was able to directly see how social class affected knowledge (Stevens 2002). Hunger does not allow a child to be able to focus on acquiring knowledge because a basic human need distracts him. Further, hunger is generally associated with the impoverished social class.

Critical pedagogy is concerned with questioning authority. It is in a way subversive. This was evident with Freire being imprisoned for his antagonistic views against the status quo which resulted in his exile. Emancipating the oppressed by challenging the beliefs and systems that dominate them is the concern of critical pedagogy. It seeks to empower the student to be critical about whatever he or she encounters. According to Ira Shor (1992) students need to look beyond the received knowledge and opinion by looking at deep meaning, social contexts and personal consequences in action, policy, subject matter, texts, and what is being said and by whom. In doing this the student is empowered to help herself against those who are subjugating her and preventing her from improving: essentially impeding her social mobility. Students are encouraged to look at the power interests, the winners and losers, the privileged groups and the status quo that protects the interests of certain groups (Kincheloe 2007). Kincheloe discussed the importance of the knowledge of the group who are being subjugated by another group. There is a liberating effect on people who learn about their own history, accomplishments, heritage and religion. It leads to empowerment through the knowledge that one comes from a group that has made a positive impact. For example the huge contribution of the Muslims world to modern civilization was conveniently overlooked in British history school textbooks:

It is to the Saracens [Muslims] that the world of today owes much of its science mathematics, astronomy, navigation, modern medicine and surgery, scientific agriculture - and their influence led to the discovery and exploration of America. In the world of the Saracens, no authority suppressed scientists, and no policeman harried them - nor did any government take care of them. They opened schools; and from Baghdad to Granada, students flocked to them. Some of these schools grew into great universities, and for hundreds of years they continued to grow (Weaver 1953: 105).

Since all education is political and teachers have their own attitudes and beliefs that they bring to classrooms, students are made aware that political agendas are in constant motion (Kincheloe 2007) and students need to be aware that oppression occurs also in gender, race, religion and class. Critical pedagogy or critical educational theory is not solely attributed to Freire. It also has distinct American roots emanating from John Dewey and continuing with civil rights activists such as Martin Luther King Jr. and Malcolm X (McLaren 2005: 183). According to Bercaw and Stooksberry (2004), critical pedagogues 'share a goal of academic success for each student, manifested in the preparation and experience of children to be active citizens in a fully democratic society'. Giroux and McLaren (1996) believe that changes need to begin in the classroom, or 'public sphere', and then move outwards as students live beyond the classroom. Although dominant powers try to perpetuate their belief system, there is the possibility that institutions especially schools can change unjust systems:

In order for teachers to be change agents of reform towards making schools public spheres, they must take a critical stance ... as transformative intellectuals who combine scholarly reflection and practice in the service of educating students to be thoughtful, active citizens (Bercaw \& Stooksberry 2004). 
In the above section I have summarized critical pedagogy and highlighted its purpose and objective. In the next section, I introduce the terms Islamic critical theory and Islamic critical pedagogy. I discuss why and how I have hybridized them to incorporate an Islamic worldview.

\section{Islamic Critical Theory}

Critical Theory is concerned with the mobilization of improvement for those who are marginalized or oppressed. Muslims living in the West are marginalized so if Critical Theory was applied to the Muslim situation it would firstly try to understand their condition, explain it and then suggest a way to give transformation. In developing an understanding for Critical Theory and critical pedagogy, I was interested in knowing what Islamic versions of the theory existed. My reason for wanting to know this was embedded in the general approach that critical theory advocates which is empowering the voiceless. I began to wonder, was there an equivalent version of Critical Theory in Islamic social sciences? If there was then it would help by allowing me to situate my study on character development and Islamic children's literature within an Islamic worldview. This is important because:

\footnotetext{
Modern epistemology, many Islamic pedagogues insist, minimizes the knowledge one derives from revelation (Wahy) and thus reduces the knowledge to a material realm wholly dependent on reason. In other words, they continue, Western thought assumes a secular starting point (Merry 2007: 52).
}

I wanted to discard secularist thought because it is antagonistic to my way of thinking. My way of thinking is informed by the English translation of the Qur'an (because I do not understand Arabic). There are scholars and researchers who are looking for alternatives to academic secularization. Duderija refers to this group as 'critical-progressive Muslim scholaractivists'. About them he says: "they are reinterpreting the normative teachings of the Muslim worldview and developing a distinctly third-way approach". This approach he says: "refuses to accept either a hegemony of Western secularism or Islamic fundamentalism" (Duderija 2013: 69). Rather it promotes the Islamic worldview or Weltanschauung which is concerned with empowering Muslims to become universal law-abiding citizens. Duderija states:

The Muslim worldview engenders a coalescing of morality and ethics and the fusion of religious and political domains. The religious, therefore, permeates through the social, cultural, legal, political, and economic spheres, thereby motivating, guiding, and directing behavior of Muslims and cultivating a law-abiding citizenry (2013: 69).

Under the spirit of Critical Theory it makes sense to use a paradigm that gives Islam and Muslims visibility and the right to dialogue from their own predilection. At this stage no distinction will be made between critical Islamic theory and Islamic critical theory. I use them interchangeably. The term critical Islamic theory and Islamic critical theory are not entirely new, they have been mentioned by three scholars Kazmi (2000); Sharify-Funk (Bahi 2008); and Sadek (2012).

\section{Islamic Critical Theory: Kazmi, Sharify-Funk and Sadek}

Yedullah Kazmi (2000) is an Indian scholar teaching in Malaysia, Meena Sharify-Funk (Bahi 2008) is from the United States, and Sadek (2012) is from Lebanon. Kazmi's article discusses how critical theory can empower a person to be interactive with the world and not withdrawn or indifferent. In Historical Consciousness and the Notion of the Authentic Self in the Qur'än: Towards an Islamic Critical Theory, Kazmi writes that once a Muslim says the shahadah or 
declaration of faith, which is a very simple line, la ila (there is no god) ha ill Allah (except God), then a critical process is initiated (2000: 394). The declaration begins in the negative, 'there is no god', or 'there is nothing that can be worshipped', or 'there is nothing worthy of worship'; and then the declaration ends, 'except God'. Kazmi (2000: 394-395) argues that once a Muslim has said this phrase and made a commitment to it then it makes action expedient:

The demand made on a Muslim is that it is not enough to just accept la ilaha illa llah, but that he/she has to do something to make the truth of the phrase happen or come to be. It is not enough for me to want to play a game; I have to work at learning the game in order to enjoy it.

My understanding of Kazmi's argument within the context of it being critical is that an individual who has entered into a relationship with God has to act in such a way that all previous mannerisms or attitudes that were against the teachings of God are relinquished. Moreover, the individual now has to behave in a way that $\mathrm{s} /$ he is speaking up against different forms of oppression. These may include oppression against oneself such as smoking or drinking, or it may be oppressing others by inflicting hurt through action or speech. Or it may be that one is witnessing oppression against others and has to speak up. This can be summed up in the following hadith (saying of Muhammad):

Whoso-ever of you sees an evil, let him change it with his hand; and if he is not able to do so, then [let him change it] with his tongue; and if he is not able to do so, then with his heart - and that is the weakest of faith (Imam Muslim).

Kazmi's use of Islamic critical theory is concerned with the struggle of the individual in life within the context of a relationship with God and the world. He emphasises the concept of justice and how it relates to what one has with the fluke of birth, 'Justice results when human beings realize that life is just a test and try their best to do well in the test'. Kazmi refers to whatever a person owns or whatever faculties a person processes is his or hers only as a trustee. This attitude prevents a person from being egotistic:

\footnotetext{
'I will have no reason to be proud of what I own or process' since possessions and talents are given by God. Hence they, as Kazmi explains, are considered a gift which has to be used in the service of God and humankind, 'obsession with one's needs to the exclusion of the needs of others is greed and greed is a form of ego-worship negated by la ilaha illa llah [there is no god but God]' (Kazmi 2000: 398).
}

Kazmi's Islamic critical theory is imbedded in the Declaration of Faith or Shahadah and works on the principle that justice and knowing oneself is relative to God. 'In Islam the road to social justice and to personal justice are not two separate roads but a single highway. You cannot achieve one without realizing the other' (Kazmi 2000: 398). Sharify-Funk has discussed Islamic critical theory in relation to the hegemonic male dominated interpretation of the Qur'an that oppresses Muslim women. She writes: "A theory of critical Islamic interpretation, like Western critical theory, is exposing the picture of hegemonic power in order to achieve an ideal of human emancipation". She also points out the difference between a critical Islamic theory and a Western critical theory; the latter she notes has a 'tendency to assume that religion is more likely to have a counter-progressive agenda, and hence remain silent or indifferent in the face of injustice'. Sharify-Funk calls for a reinterpretation of knowledge which thus far is hankered on the claim that it is 'context-free'. She is correct in saying it is not context-free; it is most assuredly biased towards males. She therefore appeals for 'an alternative approach to communal values and focuses on the interaction among text, interpreter and context' (Bahi 2008). Sharify-Funk is seen by some as part of an international group of Muslim scholars who 
are reinterpreting the Quran (Duderija 2013). Kazmi appears to be one of the pioneers of this movement. He discusses the fallacy of immobility and stagnation. 'The point, however, is not to keep society frozen in time in its pristine form by preventing it from changing'. This, he cautions would be like plucking society out of time and suspending it in a fictional space (Kazmi 2000: 395). Kazmi speaks about the Quran as a mode for all time:

If a society founded on the principles of the Quran was prevented from changing it, it would be not only not natural but one wonders if Islamic at all. For one thing, it would definitely vitiate the universality of the Quran rendering it true for one time only (Kazmi 2000: 395-396).

Kazmi tasks the Muslim world with a God centered approach, 'deconstruction and construction initiated by la ilaha illa llah [there is no god but God] is a continuous and unending process' (2000: 395). Sharify-Funk makes the point that traditional interpretation has to be challenged in its oppressive patriarchal patterns. What Sharify-Funk and Kazmi allude to is however, in my opinion, not something new, rather I feel it is in the spirit of the sunnah of Prophet Muhammad. For instance some Arab countries deny women the right to drive cars. However, the Sunnah shows that the Prophet's wife, Aysha would ride on a camel. She was not prevented from doing this. By extrapolation, the modern form of transport though still a camel in some regions can also be a motor vehicle or airplane. The prohibition of women drivers in some Arab countries therefore does not reside in a motive to be closely aligned to the way of Muhammad. Rather it is contrary to the Sunnah and designed to impede and restrict the freedom of females for ulterior motives. Sharify-Funk (2003) calls for the accountability of those who oppress. She suggests the encouragement of creating a new voice which 'hold the hegemonic state and its substructure accountable for their actions'. Whereas the traditional approach directs all attention to the authoritative text while ignoring questions about who is interpreting and under what circumstances, a critical Islamic approach balances the claims of the text with consideration of the needs and existential circumstances of the Muslim society and its interpreters. It focuses on the interaction among text, interpreter, and context (Sharify-Funk in Bahi 2008). Sadek has not developed an Islamic critical theory: "I do not have or develop an Islamic critical theory" (Sadek, personal communication March 7, 2014), rather he takes steps towards developing an Islamic critical theory. He states: "The dissertation thus, takes initial steps in developing an Islamic critical theory by putting forward a radically democratic conception of Islamic politics" (2012: iv). He explains:

Through the intellectual rapprochement between Honneth's recognition theory and Ghannouchi's political thought I take initial steps in developing an Islamic critical theory. I make these initial steps by arguing that a critical perspective that accepts the unquestionable authority of al-nass (qur'an and sunna) does not have to be authoritarian, and that such acceptance undermines neither the autonomous agency of those who employ it nor of those who are subjected to it. Capitalizing on some elements in Ghannouchi's theoretical model of the Islamic state I make explicit resources internal to the Islamic tradition that can fend off the charge that Islamic politics would be authoritarian (Sadek, personal communication February 5, 2014).

In summary Kazmi's discussion on critical Islamic theory centers on Muslims being proactive after saying the declaration of faith (shahada). Sharify-Funk's discussion centers on reinterpreting Islamic laws and texts which currently are male dominated. Sadek takes initial 'steps' in developing an Islamic critical theory that relates to a democratic concept of Islamic politics. In the next section I highlight some characteristics that I believe reflect a type of critical Islamic theory. 


\title{
Characteristics of Critical Islamic Theory
}

I am unable to establish whether there is any discussion on critical Islamic theory in languages other than English. What exists is limited to the three scholars. Despite efforts to locate SharifyFunk's article through her email, her institution and academic libraries in the UK and USA, I was limited to understanding her work though Bahi who quotes her extensively. In light of the scarcity of academic discussion on critical Islamic theory, I will in this section provide some defining characteristics of critical Islamic theory based on my assumptions of what critical Islamic theory is. My assumptions are based on my knowledge of the Quran and Sunnah. Furthermore, the critical Islamic theory I will discuss is one type of Islamic critical theory. It is by no means exclusive. Hopefully as academic interest develops in this area more variations will evolve. In providing a description of Islamic critical theory, I think it is important to quote Kincheloe and his perspective on theories. Although he writes about critical pedagogy, his words are nonetheless very relevant to any theory. I draw on Kincheloe's opinion to reflect his spirit to argue that the Islamic critical theory I am speaking of will in time be one of many:

\begin{abstract}
All descriptions of critical pedagogy - like knowledge in general - are shaped by those who devise them and the values they hold. The description offered here is no different. Many will agree with it and sing its praises, while others will be disappointed - and even offended by what was included and what was left out. As with other descriptions I would offer about any social or cultural phenomenon, my delineation of the central characteristics of critical pedagogy is merely 'my take' and reflects my biases and perspectives (Kincheloe 2004: 6).
\end{abstract}

Therefore the Islamic critical theory I speak of is grounded in the acknowledgment of one God and His encouragement for humankind to practice and engender social justice. Also grounded in this theory is the belief that humankind will be judged in the afterlife for their earthly conduct. Humankind is exhorted to encourage the doing of good deeds: "Indeed, God orders justice and good conduct and giving to relatives and forbids immorality and bad conduct and oppression. He admonishes you that perhaps you will be reminded" (Quran 16:90). The Quran's declaration of freewill is also a very important aspect of Islamic critical theory. About freedom, the Quran states: "Let there be no compulsion in religion" (2:256). A second verse states: "If it had been thy Lord's will, they would all have believed, - all who are on earth! wilt thou then compel mankind, against their will, to believe!" (10:99). Islamic belief asserts that all humankind will stand alone and answer for their deeds: "Every soul draws the meed of its acts on none but itself: no bearer of burdens can bear the burden of another" (6:164). Chapter 'Asr which is the second smallest chapter in the Quran consisting of a mere three verses epitomises the Quranic message. It calls for people to have faith and do good deeds but also encourage others to truthfulness and patience. This verse beckons humanity to strive towards building a healthy society (I allude to the similar Habermasean ideal later). Truth is a very important ingredient in creating an emancipatory world as the following verse shows:

0 ye who believe! Stand out firmly for justice, as witnesses to God, even as against yourselves, or your parents, or your kin, and whether it be (against) rich or poor: for God can best protect both. Follow not the lusts (of your hearts), lest ye swerve, and if ye distort (justice) or decline to do justice, verily God is well-acquainted with all that ye do (Quran 4:135).

As previously mentioned there are parallels between the Islamic call for the mutual encouragement of truth, patience and virtues and the Habermasean theory of communicative action. As in Islamic critical theory, which calls for people to work together to produce a just society, Habermas states: "Actors do not primarily aim at their own success but want to 
harmonize their action plans with the other participants" (Habermas 1984: 285). Amal al-salihat (good deeds) are in the language of the modern world the actions of responsible citizens. The Quran states: "Let there arise out of you a band of people inviting to all that is good, enjoining what is right, and forbidding what is wrong" (Quran 3:104). This Quranic verse is the prerogative of Islamic critical theory. Islamic critical theory is concerned with ideas about human experience, and life in general from an Islamic-centered perspective. Its initial focus is the life of a Muslim. It tries to view the social world from the vantage point of the Qur'an relative to Muslims. It seeks to create a better world for Muslims and all humankind. Islamic critical theory develops a critical understanding of society in the service of justice, service to humanity and service to God. It is grounded on the belief that humankind must be constantly aware that situations and choices are presented that may lead to wrong thought, wrong action, and wrong speech. It then suggests ways in which these can be overcome leading to right thought, right action and right speech. Islamic critical theory can be defined as recognizing, critiquing and providing normative action on any matter that oppresses the individual or the society socially, economically, scientifically, politically, psychologically or through any other medium, idea, or field.

\section{Historical Origins of Islamic Critical Theory}

Critical Theory has historical roots associating it with the Frankfurt School. Islamic critical theory also has historic roots which I believe associate it in spirit with Prophet Muhammad. In this section I discuss those historical origins. I begin with a verse from the Quran that positions Islam and Muhammad. According to Islamic belief, divine revelation has been visited on every community throughout the ages. The message has always been the same: to worship God exclusively and be cautioned about the judgment day when all individuals will interrogated on what they did in life. This has according to Islamic belief been the identical pursuit of prophets from Adam, Noah and Joseph to John, Zachariah and Muhammad:

It is He Who sent down to thee (step by step), in truth, the Book, confirming what went before it; and He sent down the Law (of Moses) and the Gospel (of Jesus) before this, as a guide to mankind, and He sent down the criterion (of judgment between right and wrong) (Quran 3:3).

The criterion is knowing what is right and wrong. Each messenger assigned to a community confirmed and admonished the same values. Muslims are taught not to make a distinction between the message and the messengers because they are the same:

The Messenger believes in what has been revealed to him from his Lord, as do the men of faith. Each one (of them) believes in God, His angels, His books, and His messengers. 'We make no distinction' (they say) 'between one and another of His messengers' (Quran 2: 285).

Messengers are sent as reformers, emancipators, or champions of human rights. Furthermore a messenger is only sent on a needs basis. Society has to have reached the lowest ebb of iniquity to cause the mobilization of a divine, human messenger. Such a time arose over fourteen hundred years ago in the Arabian Peninsula. A decadent society was in need of reform. Historians refer to this period as jahiliyah (Age of Ignorance) which was marked by barbarity and inhumanity. I draw on two Sunnah narratives to describe the change that came in Makkah as a result of the message brought through Muhammad. The first is between the king of Abyssinia and Jafar Ibn Abu Talib, the spokesperson for the Muslim refugees that were taking sanctuary in Abyssinia after fleeing Mecca. Anti-Islamic emissaries from Mecca came to the king and asked for the return of the Muslim fugitives who they accused of rebellion and lawlessness. 
The king wanted to speak to the refugees before he handed them over. In addressing the king, Jafar spoke about the transformation that had raised the human condition and led to personal and social emancipation:

0 King, we were a people in a state of ignorance and immorality, worshipping idols and eating the flesh of dead animals, committing all sorts of abomination and shameful deeds, breaking the ties of kinship, treating guests badly, and the strong among us exploited the weak. We remained in this state until God sent us a Prophet, one of our own people whose lineage, truthfulness, trustworthiness and integrity were well-known to us. He called us to worship God alone and to renounce the stones and the idols which we and our ancestors used to worship besides God. He commanded us to speak the truth, to honour our promises, to be kind to our relatives, to be helpful to our neighbours, to desist from all forbidden acts, to abstain from bloodshed, to avoid obscenities and false witness, and not to appropriate an orphan's property or slander chaste women. $\mathrm{He}$ ordered us to worship God alone and not to associate anything with Him, to uphold salah [worship], to give zakah [charity] and fast in the month of Ramadan. We believed in him and what he brought to us from God and we follow him in what he has asked us to do and we keep away from what he has forbidden us from approaching (Hamid 1995).

These emancipatory changes were violently opposed by the chieftains of Makkah. Those in authority preferred to keep things as they were and saw the effect of Islam on the marginalised as well as those in prominent positions. They envisaged Islam as a threat to their power and wealth. At the time the Kabah contained 365 idols and attracted masses of people for pilgrimage which brought wealth to the city. By Muhammad and his followers claiming that the idols were false gods, it was a threat to financial power and so it was violently opposed by the Makkan bourgeoisie. The second narrative is from the Farewell Sermon of Prophet Muhammad:

Return the goods entrusted to you to their rightful owners. Hurt no one so that no one may hurt you... You will neither inflict nor suffer any inequity... It is true that you have certain rights in regard to your women, but they also have rights over you... Do treat you women well and be kind to them, for they are your partners and committed helpers... an Arab has no superiority over a non-Arab nor a non-Arab has any superiority over an Arab; also a white has no superiority over a black, nor a black has any superiority over a white- except by piety and good action ... Do not therefore, do injustice to yourselves (The Last Sermon 2013).

The key points in the Farewell Sermon, refer to honesty, trust, non aggression, equity, kindness to women and equality. The elements of human civility that Jafar spoke of in Abyssinia and those that Muhammad spoke of in the Farewell Sermon are derived from the Quran. It is these character traits and attitudes that ensured that the weak were no longer oppressed in Makkah. A society that subscribes to these values, subscribes to safeguarding human rights. Critical Theory arose as a result of Jewish men (Kincheloe 2004: 47) who experienced the Holocaust, whilst Islamic critical theory, I would say, emerged as a result of those who experienced jahilliyah (ignorance). Both of the narratives indicate that historically the modus operandi of Islam was emancipatory and transformational.

Today, Muslims are not only marginalized in the West, but also in their own lands. Accounts of oppression against women alone are too numerous not to mention the flagrant offenses committed against those of a different colour, or social standing. There is no shortage of issues that need attention in the Muslim world. Oppression is in abundant supply. Little wonder that my initial encounter of Islamic schools in North America was so shocking. The people who were running the schools had come from regions where oppression was conventional. And when things are so habitually ingrained by the majority it is difficult to point out that it is wrong. Islamic critical theory can serve as an instrument of change and bring Islam 
out of its dark age and again into its golden age. In the next section I argue how Islamic critical theory qualifies as a critical theory.

\section{Qualifying Islamic Critical Theory as a Critical Theory}

Following on from Kincheloe's explanation of variations in theories, I make a case for a kind of Islamic critical theory as it relates to my educational practice and pertains to my subjectivity and perspectives. I base my delineation on the Weltanschuung of Islam, the Quran and Sunnah. As my quest for a good-fit theory arose from my understanding of Critical Theory, I argue my form of Islamic critical theory using Horkheimer's widely-quoted three criteria definition of a theory. Horkheimer believed that:

A critical theory is adequate only if it meets three criteria: it must be explanatory, practical and normative, all at the same time. In other words, it needs to give explanation for what is wrong with current social reality, identify the actors to change it, and provide both clear norms for criticism and achievable practical goals for social transformation (Bohman 1996: 190).

I argue that Islamic critical theory can critique every aspect of life and present a solution that is in harmony with the teachings of the Quran and Sunnah and can lead to emancipation, transformation and a better life. I will apply Horkheimer's definition to this theory point by point to show that it qualifies as a critical theory in contemporary society. I use two examples. The first refers to my study on character development and Islamic children's fiction, the second to forced marriages.

The first part of Horkheimer's criteria is 'explanatory'. An explanation must be provided about what is wrong with the 'current social reality'. Using the example of my study, Islamic critical theory would say that the behaviour of some Muslim children in school is oppressive towards other Muslim children. This is the critique of 'what is'. Children say unkind words and physically hurt others. The second criterion is that the theory must be 'practical' this means that 'actors' must be identified 'to change' the oppression. Or as How (2003: 9) indicates, 'what should be'. Actors identified to make the change are teachers and students. What should be, is a safe and oppression-free learning environment. Horkheimer's third qualification asks that a critical theory be normative. This means that it must 'provide both clear norms for criticism and achievable goals for social transformation'. The 'better life' is achieved when the individual is emancipated from the oppression of unkind words, and physical assault. This can be actualized through literature-based character development, modeling right action and right speech and creating opportunities for children to use terms and phrases against perpetrators or oppressors. This is transferred to the whole school so that everyone can buy into the process of stopping oppressive behaviour. The combined mechanics of teachers and students through empowered training results in an environment that is safe and oppression free.

My second example refers to forced marriage which although may be practiced by a few, receives massive amplification in British media to reinforce a negative image of Muslims. Neverthe-less we can use it here as an example. The explanatory stage or the identification stage is that there are individuals who are being forced to marry someone against their wish. The second stage or practical stage consists of two paths. One is to educate the oppressor and the other is to educate the oppressed with the Quran and Sunnah. Forced marriages in Islam are not recognized, they are null and void in Shariah law. A woman cannot be forced to marry against her will. Actors who can create transformation may be community members who are knowledgeable about the faith, or indeed the oppressed themselves can locate texts that show their oppressors that forced marriage is against the laws of Islam. The final stage or the normative stage results in the removal of oppression and transformation to freedom which can result either through oppressors understanding their error, or through civil disobedience on the 
part of the oppressed based on the belief that God's laws are superior to man's oppressive inclinations. In this way the marriage does not take place and there is a feeling of emancipation.

In sum, I have argued that Islamic critical theory qualifies as a critical theory because it is explanatory, practical and normative. When I initially began reading about Critical Theory and critical pedagogy, it occurred to me that there had to be equivalent theories with Islamic worldviews counterbalancing the secular based theories. I looked for them in academic libraries in the United States, in Canada and in England but I did not find them except for Sadek's work which is currently restricted to his thesis and Kazmi's work which is evident in an article and Sharify-Funk's work which was a conference paper and only accessible to me second hand. Therefore it seems reasonable to assume that Islamic theories are not easily accessible to Muslim researchers, even if they exist. Upon my understanding of Critical Theory I learned that it concerned itself with giving voice and action to those who are marginalised. I learned that Critical Theory was about transformative empowerment. The first burden of Critical Theory is to ask questions relating to oppression, marginality, invisibility, and silence. These questions can also be directed at theories. Critical Theory suggested that Islamic theories were invisible. It suggested transformation by removing the silence and developing an Islamic theory. It is for the acknowledgement of an Islamic world view that I have developed Islamic critical theory. I have shown that it has validation as a critical theory. I believe Islamic critical theory can provide researchers with a coherent theoretical framework aligned to an Islamic worldview.

\section{References}

Adorno, T. W. \& Horkheimer, T.W. 1997. Dialectic of enlightenment. New York: Verso Classics.

Bahi, R. A. 2008. Networking for power and change: Muslim women activism and the transformation of Muslim public sphere. http://iris.lib.neu.edu/cgi/viewcontent. cgi?article=1003\&context=pub_int_aff_diss. [29/08/2013].

Bohman, J. 1996. Critical Theory and Democracy. In D.M. Rasmussen (Ed.). The handbook of Critical Theory, pp. 190-215. Oxford: Blackwell.

Bercaw, L. \& Stooksberry, L. 2004. Teacher education, critical pedagogy, and standards: An exloration of theory and practice. http://www.usca.edu/essays/vol122004/bercaw.pdf $[1 / 10 / 2013]$.

Breuing, M. 2011. Problematizing Critical Pedagogy. The International journal of Critical Pedagogy 3(3): 2-23.

Duderija, A. 2013. Critical-progressive Muslim thoughts: Reflections on its political ramifications. The Review of Faith \& International Affairs 11(3): 69 - 79.

Duncan-Andrade, J. \& Morrell, E. 2008. The art of Critical Pedagogy: The promise of moving from theory to practice in urban schools. New York: Peter Lang.

Freire, P. 1972. Pedagogy of the oppressed. Harmondsworth: Penguin.

Giroux, H. A. \& McLaren, P. 1986. Teacher education and the politics of engagement: The case for democratic schooling. Harvard Educational Review 56(3): 213-38.

Habermas, J. 1984. The theory of communicative action. Vol.1. Massachusetts: Beacon Press.

Hamid, A. 1995. The fountain of life, knowledge and belief. http://www.fountainmagazine.com/Issue/detail/Jafar-Ibn-Abi-Talib. [20/09/2013].

How, I. 2003. Critical Theory. Basingstoke: Palgrave Macmillan.

Huttunen, J. 2011. Derrida's deconstruction contra Habermas's Communicative Reason and the fate of education. http://eepat.net/doku.php?id=derrida_s_deconstruction_contra_ habermas_communicative_reason.

Jessop, S. 2012. Critical Theory and education. http://www.philosophy-ofeducation.org/uploads/papers2012/Jessop_S.pdf. 
Kazmi, Y. 2000. Historical consciousness and the notion of the authentic self in the Qur'ān: Towards an Islamic Critical Theory. Islamic Studies 39(3): 375-398.

Kellner, D. (n.d.) Marxian Perspectives on educational philosophy: From classical Marxism to Critical Pedagogy. http://www.gseis.ucla.edu/faculty/kellner.

Kincheloe, J. 2004. Critical Pedagogy Primer. New York: Peter Lang Publishing.

McLaren, P. 2005. Red Seminars: Radical excursions into educational theory, cultural politics, and pedagogy. n.p.: Hampton Press.

McLaughlin, N. 1999. Origin myths in the Social Sciences: Fromm, the Frankfurt School and the emergence of Critical Theory. Canadian Journal of Sociology 24(1): 109-140.

Merry, M. 2007. Culture, Identity, and Islamic schooling. New York: Palgrave Macmillan.

Sadek, K. 2012. Islamic Democracy: The struggle for and the limits of recognition. Washington DC: Georgetown University.

Shor, I. 1992. Empowering education: Critical teaching for social change. Chicago: U of Chicago Press.

Stevens, C. 2002. About Critical Pedagogy on the web. http://mingo.infoscience.uiowa.edu/ $\sim$ stevens/critped/page1.htm.

Strauss, J. 2012. Introduction to Sociology of Education. www.calstatela.edu/faculty/ jstraus/Week_9.pp.

The Last Sermon of the Prophet. 2013. http://www.soundvision.com/info/hajj/lastsermon.asp.

Weaver, H. 1953. The mainspring of human progress talbot books. http://mises.org/books/mainspring.pdf. 